\title{
EL CONTROL DE CONVENCIONALIDAD EN LA ERA DEL CONSTITUCIONALISMO DE LOS DERECHOS. COMENTARIO A LA SENTENCIA DE LA CORTE SUPREMA DE CHILE EN EL CASO DENOMINADO EPISODIO RUDY CÁRCAMO RUIZ DE FECHA 24 MAYO DE 2012
}

\author{
Gonzalo Aguilar Cavallo ${ }^{1}$ \\ Profesor de Derecho, Universidad Andrés Bello \\ gaguilarch@hotmail.com
}

\section{INTRODUCCIÓN}

Con fecha 24 de mayo de 2012, la Corte Suprema de Chile, dictó sentencia en los recursos de casación interpuestos, por un lado, por la defensa de los sentenciados y, por otro, por la asesoría letrada del Programa de la Ley No 19.123 del Ministerio del Interior con el objeto de anular la sentencia de fecha 15 de enero de 2010 pronunciada por la Corte de Apelaciones de Concepción. En esta sentencia la Corte Suprema confirma su jurisprudencia constante de los últimos años en relación con las desapariciones forzadas ocurridas durante la época de la dictadura militar y particularmente aplica el derecho internacional de los derechos humanos y el derecho internacional humanitario.

Con todo, uno de los aspectos de esta sentencia que nos interesa en este breve comentario resaltar, es la realización concreta de un control de convencionalidad por parte de la Corte Suprema. Respecto de los Convenios de Ginebra este control de convencionalidad es explícito. En cuanto a las normas y jurisprudencia interamericana se trata de un control de carácter implícito.

En este análisis se expondrán brevemente los hechos, luego se hará una sucinta exposición de los argumentos de las partes y además, se seguirá el razonamiento del tribunal. A continuación realizaremos una valoración de las enseñanzas que

\footnotetext{
${ }^{1}$ Abogado (Chile), Doctor en Derecho (España), Magíster en Relaciones Internacionales (España), Master en Derechos Humanos y Derecho Humanitario (Francia). Postdoctorado en el Max Planck Institute for Comparative Public Law and International Law (Heidelberg, Alemania). Profesor de Derecho de la Universidad Andrés Bello (Santiago, Chile) y de la Universidad de Valparaíso (Valparaíso, Chile).
} 
se pueden extraer de la sentencia, comenzando con una breve explicación de la doctrina del control de convencionalidad y de su importancia, para luego efectuar un análisis de la práctica relativa al control de convencionalidad que gradualmente asume el máximo tribunal chileno, y su contextualización en el ámbito de la humanización del Derecho del siglo XXI y del paradigma de los derechos humanos.

\section{HeCHOS}

1. Mediante resolución del 15 de enero de 2010, se resolvió castigar a los encausados Hugo Nelson González D’Arcangeli, Víctor Ernesto Donoso Barrera, Conrado Alfredo Sesnic Guerricabeitía, Osvaldo Francisco Harnish Salazar y José Raúl Cáceres González a sufrir cada uno la pena de quinientos cuarenta y un días de presidio menor en su grado medio, accesorias legales pertinentes y a enterar las costas del juicio, todo por sus responsabilidades de autores en el delito de secuestro calificado en la persona de Rudy Cárcamo Ruiz, llevado a cabo a partir del 27 de noviembre de 1974, en la ciudad de Talcahuano. En cuanto a beneficios alternativos, en atención a cumplir con los requisitos de la Ley No 18.216, se favoreció a los cinco enjuiciados con la remisión condicional de la pena.

2. La anterior decisión fue recurrida de apelación por todos los sentenciados; en tanto que la parte querellante particular y el Programa de la Ley No 19.123 del Ministerio del Interior, dedujeron igual medio de impugnación. Una Sala de la Corte de Apelaciones de Concepción, por dictamen de 25 de noviembre de dos mil once, procedió a confirmarla en todas sus partes.

3. Contra el anterior pronunciamiento de segundo grado, se entablaron sendos recursos de casación en el fondo; el primero, correspondiente a la defensa de los sentenciados Hugo Nelson González D’Arcangeli, Víctor Ernesto Donoso Barrera, Conrado Alfredo Sesnic Guerricabeitía y José Raúl Cáceres González, sustentado en la motivación séptima del artículo 546 del Código de Procedimiento Penal; y a continuación, la asesoría letrada del Programa de la Ley No 19.123 del Ministerio del Interior, interpuso el propio, por la causal $1^{\text {a }}$ de la norma ya citada.

\section{POSICIÓN DE LAS PARTES}

1. La defensa de los sentenciados planteó el recurso de casación fundado en que "la sentencia de segundo grado vulneró leyes reguladoras de la prueba, con influencia sustancial en lo dispositivo de la sentencia". 
2. El error que se denuncia consistió en determinarse la intervención de sus defendidos como propia de autores del delito investigado, aunque también se aprecia un cuestionamiento a la calificación jurídica de secuestro calificado.

3. La defensa también esgrime que el hecho punible se estableció en base a presunciones que vulneran las leyes reguladoras de la prueba, para luego afirmar que la discusión se reduce a determinar la participación.

4. Como conclusión, la defensa señala "que la errada aplicación de la ley causó a sus defendidos un agravio o perjuicio al condenárseles como autores de un delito, en circunstancias que no lo eran, por lo que se solicita que se acoja su libelo, se anule la sentencia recurrida y se dicte otra de reemplazo por la que se resuelva la absolución de sus defendidos".

5. En cuanto al recurso interpuesto por el Programa de la Ley No 19.123 del Ministerio del Interior "se precisa que los jueces del fondo desconocieron la improcedencia de la atenuante contenida en el artículo 103 del Código Penal, referida a la media prescripción". ${ }^{2}$

6. El Programa del Ministerio del Interior señala que en el fallo de los jueces del fondo "se determinó acertadamente el carácter imprescriptible e inamnistiable del delito investigado", por lo que no aparece lógico ni jurídico aplicar la media prescripción, olvidando los jueces del fondo que la prescripción es una norma reguladora de la prescripción y, en ese sentido, jurídicamente conforma una misma institución que tiene como fundamento base el transcurso del tiempo, mientras la prescripción de la acción penal extingue la responsabilidad criminal, la prescripción gradual confiere al juez un poder discrecional para atenuar la sanción. "Por ello es que al tratarse de delitos imprescriptibles pierde sentido conceder beneficios derivados de la prescripción gradual toda vez que la esencia de ésta reside en estar sometida a límites de tiempo". ${ }^{3}$

7. El Programa del Ministerio del Interior finalmente concluye que la aplicación de la prescripción gradual a los sentenciados "les permitió una considerable rebaja de la sanción y el otorgamiento de beneficios alternativos al del cumplimiento efectivo de las condenas, lo que se tradujo en una pena no proporcionada al crimen cometido y la sanción aparece como una apariencia de

\footnotetext{
${ }^{2}$ Corte Suprema: Secuestro calificado de Rudy Cárcamo Ruiz. Recurso de Casación. Rol No 288-12. Sentencia de fecha 24 de mayo de 2012. Considerando $28^{\circ}$.

${ }^{3}$ Corte Suprema: Secuestro calificado de Rudy Cárcamo Ruiz. Recurso de Casación. Rol No 288-12. Sentencia de fecha 24 de mayo de 2012. Considerando $29^{\circ}$.
} 
justicia, que deja a sus autores sometidos a castigos irrisorios y desproporcionado en libertad, por lo que solicita que se acoja su recurso, se anule la sentencia atacada y se dicte otra de reemplazo en la que se decida confirmar la sentencia condenatoria de primer grado con declaración que se les imponga el máximo de la pena privativa de libertad considerada por el legislador". ${ }^{4}$

\section{RAZONAMIENTO DEL JUEZ SUPREMO}

1. La Corte Suprema afirma que el defensor invoca una causal como vulnerada pero en realidad cuestiona hechos o situaciones correspondientes a dos causales de casación distintas, "lo que desde luego obsta a su procedencia, ya que este tribunal, dada la naturaleza extraordinaria y de derecho estricto del presente recurso, queda imposibilitado para pronunciarse sobre una causal cuyos fundamentos y objetivo son propios de otra muy distinta". 5

2. Además, los sentenciadores señalan que "el impugnante no atribuye a los juzgadores haber fundado su decisión en algún elemento probatorio no contemplado en la ley; en todo caso, con claridad se advierte del pronunciamiento que se ha recurrido a las presunciones para tener por acreditado el injusto, medio contemplado expresamente como idóneo en el artículo 457 de la recopilación procesal penal". ${ }^{6}$

3. Lo anterior, indica el Tribunal, "ponen en evidencia las graves imprecisiones en que se ha incurrido en la formalización del libelo, que son contrarias a su naturaleza y fines y siendo el recurso de casación de derecho estricto y no pudiendo por ello admitírselo cuando se basa en razonamientos errados, incompletos o contradictorios, como se ha demostrado que lo son los desarrollados en el caso 'sub-lite', no resta otra solución que su rechazo". ${ }^{7}$

4. Junto con lo anterior, los jueces del tribunal superior indican que "se debe considerar que los jueces del fondo son soberanos en cuanto al establecimiento de los hechos y a la valoración o ponderación de la prueba que obra

\footnotetext{
${ }^{4}$ Corte Suprema: Secuestro calificado de Rudy Cárcamo Ruiz. Recurso de Casación. Rol No 288-12. Sentencia de fecha 24 de mayo de 2012. Considerando $30^{\circ}$.

5 Corte Suprema: Secuestro calificado de Rudy Cárcamo Ruiz. Recurso de Casación. Rol No 288-12. Sentencia de fecha 24 de mayo de 2012. Considerando $11^{\circ}$.

${ }^{6}$ Corte Suprema: Secuestro calificado de Rudy Cárcamo Ruiz. Recurso de Casación. Rol No 288-12. Sentencia de fecha 24 de mayo de 2012. Considerando $16^{\circ}$.

${ }^{7}$ Corte Suprema: Secuestro calificado de Rudy Cárcamo Ruiz. Recurso de Casación. Rol No 288-12. Sentencia de fecha 24 de mayo de 2012 . Considerando $12^{\circ}$.
} 
en el proceso, sin que la distinta apreciación que de esta última pueda hacer el recurrente y conforme a la cual llega a conclusiones diversas, como queda en evidencia del análisis de su libelo, faculte a esta Corte para revisar la decisión cuestionada por no quedar tal devenir dentro de la esfera de control de este Tribunal de Casación, desde que le está vedado entrar a examinar y aquilatar los instrumentos probatorios mismos que ya han sido justipreciados por los jurisdicentes del grado en el ejercicio de sus atribuciones privativas, así como revisar las conclusiones a que ellos han llegado, ya que eso importaría desnaturalizar el arbitrio en estudio, que debe fundarse exclusivamente en cuestiones de derecho". ${ }^{8}$

5. En cuanto al recurso deducido por el Programa de la Ley No 19.123 del Ministerio del Interior, particularmente, fundado en la aplicación de la media prescripción o prescripción gradual, el máximo tribunal sostiene que "atendida la naturaleza del hecho pesquisado y con arreglo a los antecedentes reunidos durante la indagación, es procedente inferir que se está en presencia de lo que la conciencia jurídica universal ha dado en denominar delito contra la humanidad". ${ }^{\circ}$

6. Además, los jueces del máximo tribunal mantienen que "[e]fectivamente, el ilícito fue perpetrado en un contexto de violaciones a los derechos humanos graves, masivas y sistemáticas, verificadas por agentes del Estado, constituyendo la víctima un instrumento dentro de una política a escala general de exclusión, hostigamiento, persecución o exterminio de un grupo de numerosos compatriotas, integrado por políticos, trabajadores, estudiantes, profesionales, adolescentes, menores y todo aquel que, en la fecha inmediata y posterior al once de septiembre de mil novecientos setenta y tres, fue sindicado de pertenecer ideológicamente al régimen político depuesto o que, por cualquier circunstancia, fuera considerado sospechoso de oponerse o entorpecer la realización de la construcción social y política proyectada por los sublevados, garantizando la impunidad a los ejecutores de dicho programa mediante la no interferencia en sus métodos, tanto con el ocultamiento de la realidad ante las peticiones de los tribunales ordinarios de justicia, como por la utilización del poder estatal para persuadir a la opinión pública local y extranjera que

\footnotetext{
${ }^{8}$ Corte Suprema: Secuestro calificado de Rudy Cárcamo Ruiz. Recurso de Casación. Rol No 288-12. Sentencia de fecha 24 de mayo de 2012. Considerando $21^{\circ}$.

9 Corte Suprema: Secuestro calificado de Rudy Cárcamo Ruiz. Recurso de Casación. Rol No 288-12. Sentencia de fecha 24 de mayo de 2012 . Considerando $31^{\circ}$.
} 
las denuncias formuladas al efecto eran falsas y respondían a una campaña orquestada encaminada a desprestigiar al gobierno autoritario". ${ }^{10}$

7. La Corte Suprema afirma enseguida que los hechos de la causa "no cabe duda alguna que deben ser subsumidos a la luz del derecho internacional humanitario dentro de la categoría de crímenes contra la humanidad. El secuestro realizado por agentes del Estado -o por un individuo que actúa con autorización, apoyo o aquiescencia oficial-, es un caso de privación de libertad que conculca, además de la libertad ambulatoria, el derecho del detenido a ser llevado sin demora ante un juez y a deducir los recursos apropiados para controlar la legalidad de su 'arresto' y que conlleva el aislamiento prolongado y la incomunicación coactiva de la víctima, la negación de su detención y reclusión a terceros interesados, que representan, por sí mismas, formas de tratamiento cruel e inhumano, lesivas de la integridad síquica y moral y del debido respeto a la dignidad inherente al ser humano; configuran, por tanto, una violación múltiple y continuada de numerosos derechos, que ha sido calificada por la Asamblea de la Organización de Estados Americanos como 'una afrenta a la conciencia del Hemisferio y constituye un crimen de lesa humanidad' (AG/ RES 666), que la comunidad mundial se ha comprometido a erradicar, pues tales hechos merecen una reprobación categórica de la conciencia universal, al atentar contra los valores humanos fundamentales, que ninguna convención, pacto o norma positiva puede derogar, enervar o disimular". ${ }^{11}$

8. El Tribunal Superior continúa su argumentación afirmando que "en la medida que los acontecimientos pesquisados configuran crímenes contra la humanidad, de ellos deviene como lógico corolario la inexorabilidad de su juzgamiento y su consiguiente imprescriptibilidad, desde que los ilícitos contra la humanidad son delitos contra el derecho de gentes que la comunidad mundial se ha comprometido a erradicar". ${ }^{12}$

9. Finalmente, en esta línea de argumentación, los jueces superiores señalan que "en armonía con ello y en vista de la evolución del derecho internacional de los derechos humanos, los hechos sobre los que versa este litigio son imprescrip-

\footnotetext{
${ }^{10}$ Corte Suprema: Secuestro calificado de Rudy Cárcamo Ruiz. Recurso de Casación. Rol No 288-12. Sentencia de fecha 24 de mayo de 2012. Considerando $31^{\circ}$.

${ }^{11}$ Corte Suprema: Secuestro calificado de Rudy Cárcamo Ruiz. Recurso de Casación. Rol No 288-12. Sentencia de fecha 24 de mayo de 2012. Sentencia de Reemplazo. Considerando $15^{\circ}$.

${ }^{12}$ Corte Suprema: Secuestro calificado de Rudy Cárcamo Ruiz. Recurso de Casación. Rol No 288-12. Sentencia de fecha 24 de mayo de 2012. Considerando $33^{\circ}$.
} 
tibles, desde que es obligatoria para el derecho chileno la normativa del Derecho Internacional Penal de los Derechos Humanos para el cual es inadmisible la prescripción que pretenda imposibilitar la investigación de violaciones graves de los derechos humanos y la sanción, en su caso, de los responsables". ${ }^{13}$

10. Finalmente, la Corte Suprema acoge el recurso de casación interpuesto por el Programa de la Ley No 19.123 del Ministerio del Interior, ya que la sentencia de impugnada "equivocadamente se acogió el reconocimiento de la denominada 'media prescripción' y de la rebaja de la pena que se solicitaba por dichas defensas como consecuencia de su aceptación”. ${ }^{14}$

11. En la sentencia de reemplazo, los jueces del máximo tribunal confirman el valor fundamental del artículo $3^{\circ}$ común a los cuatro Convenios de Ginebra. Es comúnmente aceptado que este artículo contiene un núcleo de derechos inderogables que constituyen el reflejo de normas imperativas o de ius cogens. Para su desarrollo, la Corte Suprema recurre a las explicaciones de la doctrina reflejada en el comentario a dicho artículo $3^{\circ}$ del célebre Jean Pictet. ${ }^{15}$ En efecto, refiriéndose a los ámbitos de aplicación de las normas de los Convenios de Ginebra, la Corte expresa que "[e]xcepcionalmente, se emplean en caso de 'conflicto armado sin carácter de internacional', conforme a lo prevenido en el artículo $3^{\circ}$ común para todos los Convenios de Ginebra, dado que 'por útiles que sean, pues, las diversas condiciones antes enunciadas, no son indispensables, ya que ningún Gobierno puede sentirse molesto por respetar, en la confrontación con sus adversarios internos y sea cual fuere la denominación del conflicto que lo opone a ellos, un mínimo de normas que respeta de hecho todos los días, en virtud de sus propias leyes, e incluso en el trato de vulgares criminales de derecho común'. Refuerza lo anterior que el propósito de dichos Convenios es exclusivamente humanitario y que sólo garantiza el respeto mínimo de normas que los pueblos civilizados consideran como válidas en todas partes y circunstancias, por estar por encima y fuera incluso de confrontaciones bélicas, y cuya observancia no

\footnotetext{
13 Corte Suprema: Secuestro calificado de Rudy Cárcamo Ruiz. Recurso de Casación. Rol No 288-12. Sentencia de fecha 24 de mayo de 2012. Considerando $34^{\circ}$.

14 Corte Suprema: Secuestro calificado de Rudy Cárcamo Ruiz. Recurso de Casación. Rol No 288-12. Sentencia de fecha 24 de mayo de 2012. Considerando $37^{\circ}$.

15 Pictet, Jean: "Comentario del artículo 3 común a los Convenios de Ginebra y relativo a la protección de las víctimas de los conflictos armados sin carácter internacional”, en Comentario del Protocolo del 8 de junio de 1977 adicional a los Convenios de Ginebra del 12 de agosto de 1949 relativo a la protección de las víctimas de los conflictos armados sin carácter internacional (Protocolo II) y del artículo $3^{\circ}$ de estos Convenios. Colombia: CICR - Plaza \& Janés Editores Colombia S. A., 1998.
} 
está subordinada a deliberaciones preliminares sobre la índole del conflicto o de las disposiciones particulares que han de respetarse. Lo contrario sería pretender que en casos de disturbios internos que el gobierno de turno calificara, con justo motivo, de simples actos de bandidaje y dado que el artículo $3^{\circ}$ en examen no es aplicable, aquel tiene derecho a dejar a los heridos sin asistencia, a infligir torturas o mutilaciones o a realizar ejecuciones sumarias". ${ }^{16}$

12. Además, los jueces supremos, razonan en la sentencia de reemplazo que "en tales condiciones este tribunal sólo puede colegir que en la época en que ocurrió el hecho ilícito que da origen a este pleito, el territorio nacional se encontraba en la realidad y jurídicamente en estado de guerra interna, lo que es suficiente para tener por establecido que en Chile existía un 'conflicto armado no internacional', en los términos del artículo $3^{\circ}$ común para los Convenios de Ginebra, pues sus disposiciones no son sino la afirmación, cada vez renovada, que las víctimas de conflagraciones armadas son antes que todo seres humanos y ni siquiera la guerra puede privarlos del mínimo que el respeto por el individuo exige. Por graves que puedan ser ciertas acciones y por culpables que puedan ser los responsables de determinadas acciones, no es posible admitir que el poder pueda ejercerse sin restricción alguna o que el Estado pueda valerse de cualquier procedimiento para alcanzar sus fines, sin sujeción al derecho o a la moral. En definitiva, ninguna actividad del Estado puede fundarse sobre el desprecio a la dignidad humana". ${ }^{17}$

13. Finalmente, la Corte Suprema, en función, inter alia, de estos argumentos de derecho internacional humanitario y de derechos humanos concluye que "no procede en la especie reconocer a ninguno de los enjuiciados la minorante contenida en el artículo 103 del Código Penal”, conocida como la prescripción gradual. La decisión de la sentencia de reemplazo fue adoptada por cuatro votos a favor, un voto en contra y dos prevenciones.

\section{VALORACIÓN}

1. Dentro de los elementos destacables de la sentencia de la Corte Suprema en comento se encuentra la realización en concreto (implícita y explícitamente) de un control de convencionalidad. Por esta razón, en primer lugar nos

\footnotetext{
${ }^{16}$ Corte Suprema: Secuestro calificado de Rudy Cárcamo Ruiz. Recurso de Casación. Rol No 288-12. Sentencia de fecha 24 de mayo de 2012. Sentencia de Reemplazo. Considerando $8^{\circ}$.

17 Corte Suprema: Secuestro calificado de Rudy Cárcamo Ruiz. Recurso de Casación. Rol No 288-12. Sentencia de fecha 24 de mayo de 2012. Sentencia de Reemplazo. Considerando $11^{\circ}$.
} 
referiremos a la trayectoria de la doctrina del control de convencionalidad, a su contenido y a su conceptualización (A y B), para luego examinar el control explícito e implícito de convencionalidad, particularmente, la sentencia de la Corte Suprema en el caso sobre el secuestro calificado de Rudy Cárcamo Ruiz, de 2012 (C y D). Finalmente, insertaremos el control de convencionalidad en un contexto más amplio de análisis, vinculado con la noción de Estado de Derecho internacional (E).

\section{A. La trayectoria de la doctrina interamericana del control de convencionalidad}

2. La noción de control de convencionalidad tiene ciertamente sus desarrollos más tempranos en el derecho interno de los Estados y, más particularmente, en la esfera del derecho constitucional. Esta noción encontró en la doctrina constitucional francesa y sobre todo en la jurisprudencia de sus órganos jurisdiccionales un terreno fértil.

3. En el ámbito de la Corte Interamericana de Derechos Humanos (en adelante, la Corte IDH), el ex juez García Ramírez comenzó a dar luces a este respecto, utilizando el concepto de control de convencionalidad a través de sus votos particulares. ${ }^{18}$

4. El control de convencionalidad es asumido, por primera vez, como una doctrina de toda la Corte Interamericana en el fallo Almonacid Arellano y otros vs. Chile de 2006. En este fallo, la Corte Interamericana manifestó:

"La Corte es consciente que los jueces y tribunales internos están sujetos al imperio de la ley y, por ello, están obligados a aplicar las disposiciones vigentes en el ordenamiento jurídico. Pero cuando un Estado ha ratificado un tratado internacional como la Convención Americana, sus jueces, como parte del aparato del Estado, también están sometidos a ella, lo que les obliga a velar porque los efectos de las disposiciones de la Convención no se vean mermadas por la aplicación de leyes contrarias a su objeto y fin, y que desde un inicio carecen de efectos jurídicos. En otras palabras, el Poder Judicial debe ejercer una especie de 'control de convencionalidad' entre las normas jurídicas internas que aplican en los casos concretos y la Convención Americana sobre Derechos Humanos. En

\footnotetext{
${ }^{18}$ Corte IDH: Caso Myrna Mack Chang vs. Guatemala. Fondo, Reparaciones y Costas. Sentencia de 25 de noviembre de 2003. Serie C No 101. Voto concurrente razonado del juez Sergio García Ramírez, para. 27; Corte IDH: Caso López Álvarez vs. Honduras. Fondo, Reparaciones y Costas. Sentencia de 1 de febrero de 2006. Serie C No 141. Voto razonado del juez Sergio García Ramírez, para. 30.
} 
esta tarea, el Poder Judicial debe tener en cuenta no solamente el tratado, sino también la interpretación que del mismo ha hecho la Corte Interamericana, intérprete última de la Convención Americana". ${ }^{19}$

5. Luego, esta doctrina se incorpora reiteramente en una pluralidad de casos. Uno de los últimos fallos en los que se ha hecho mención al control de convencionalidad es el caso Atala Riffo y Niñas vs. Chile, de 2012. Aparece claramente como algo sintomático el hecho de que la obligación estatal de efectuar un control de convencionalidad sea reiterado también en casos relativos a Chile. En el caso Atala, la Corte Interamericana reiteró que:

"[C] onforme lo ha establecido en su jurisprudencia previa, este Tribunal recuerda que es consciente que las autoridades internas están sujetas al imperio de la ley y, por ello, están obligadas a aplicar las disposiciones vigentes en el ordenamiento jurídico. Pero cuando un Estado es Parte de un tratado internacional como la Convención Americana, todos sus órganos, incluidos sus jueces y demás órganos vinculados a la administración de justicia, también están sometidos a aquél, lo cual les obliga a velar para que los efectos de las disposiciones de la Convención no se vean mermados por la aplicación de normas contrarias a su objeto y fin (...) Los jueces y órganos vinculados a la administración de justicia en todos los niveles están en la obligación de ejercer ex officio un 'control de convencionalidad' entre las normas internas y la Convención Americana, en el marco de sus respectivas competencias y de las regulaciones procesales correspondientes. En esta tarea, los jueces y órganos vinculados a la administración de justicia deben tener en cuenta no solamente el tratado, sino también la interpretación que del mismo ha hecho la Corte Interamericana, intérprete última de la Convención Americana”. ${ }^{20}$

6. Desde una perspectiva comparada, dentro de las singularidades que presenta la formulación por la Corte IDH del control de convencionalidad en el caso Atala (2012) en relación con la versión del caso Almonacid (2006), se pueden resaltar tres aspectos:

a) El caso Almonacid se refiere al control de convencionalidad como una obligación que recae sobre los jueces, mientras que el caso Atala alude a "todos sus órganos, incluidos sus jueces y demás órganos vinculados a la administración de

\footnotetext{
${ }^{19}$ Corte IDH: Caso Almonacid Arellano y otros vs. Chile. Excepciones Preliminares, Fondo, Reparaciones y Costas. Sentencia de 26 de septiembre de 2006. Serie C No 154, para. 124.

${ }^{20}$ Corte IDH: Caso Atala Riffo y Niñas vs. Chile. Fondo, Reparaciones y Costas. Sentencia del 24 de febrero de 2012. Serie C No 239, paras. 281-282.
} 
justicia”, lo cual amplifica y extiende los órganos estatales encargados de velar por la convencionalidad;

b) El caso Almonacid se refiere a las leyes contrarias a la Convención Americana sobre Derechos Humanos, en circunstancias que la sentencia Atala alude a las normas contrarias a la Convención Americana sobre Derechos Humanos, lo cual implica un concepto un poco más amplio que la mera consideración de la ley;

c) El caso Almonacid no alude a ninguna obligación de proceder de oficio, mientras que el caso Atala se refiere a que el control de convencionalidad es una obligación que los jueces deben ejercer ex officio.

7. Por último, resulta muy interesante destacar que la Corte IDH en el caso Atala resalta la idea original del caso Almonacid de que 'los jueces y órganos vinculados a la administración de justicia deben tener en cuenta no solamente el tratado, sino también la interpretación que del mismo ha hecho la Corte Interamericana', cuando agrega que:

"[...] con base en el control de convencionalidad, es necesario que las interpretaciones judiciales y administrativas y las garantías judiciales se apliquen adecuándose a los principios establecidos en la jurisprudencia de este Tribunal [...]". ${ }^{21}$

Como se verá más adelante, la Corte Suprema y otros órganos judiciales han emprendido -correctamente a nuestro entender- la vía de la interpretación del derecho conforme a los principios establecidos en la jurisprudencia interamericana. Esta práctica judicial, no sólo apunta en la dirección correcta para la debida protección de los derechos humanos sino que además cumple con las obligaciones convencionales que el Estado de Chile ha contraído. Abordaremos ahora en forma muy sucinta la conceptualización del control de convencionalidad.

\section{B. El concepto de control de convencionalidad}

8. El control de convencionalidad es una teoría que ha nacido en el ámbito interno de los Estados en relación con las normas internacionales. El control de convencionalidad alude a la facultad de los magistrados de contrastar la norma dictada por el poder legislativo $-y$, eventualmente, por el poder constituyente- con la norma contenida en los tratados internacionales que han sido ratificados por el Estado para hacer prevalecer estas últimas sobre las normas

${ }^{21}$ Corte IDH: Caso Atala Riffo y Niñas vs. Chile. Fondo, Reparaciones y Costas. Sentencia del 24 de febrero de 2012. Serie C No 239, para. 284. 
emanadas del poder legislativo y, a fortiori, sobre las normas emanadas del poder ejecutivo. ${ }^{22}$

9. La noción de control de convencionalidad ha tenido su origen en el derecho interno de los Estados, como consecuencia de la incorporación del derecho internacional al derecho interno y, por lo tanto, de la presencia dentro del ordenamiento estatal de normas cuyo origen no ha estado en el ejercicio del monopolio estatal sino en el resultado del acuerdo o convención entre dos o más Estados. De este modo, las normas internacionales son, desde el punto de vista de su órgano o forma de producción, extrañas al ordenamiento estatal. Entre las reglas generales de solución de conflicto de normas, esto es, las reglas que le introducen un principio de orden al conjunto normativo estatal, se encuentra la regla de la jerarquía. Según esta regla todas las reglas tienen su fuente de validez en una norma superior y de este modo es posible remontarse hasta la regla suprema, que justifica la validez de todas las demás, y que se encuentra en la cúspide del conjunto normativo. Esta regla que ocupa la cima de la estructura normativa estatal es la Constitución. A partir de la Segunda Guerra Mundial, se ha reconocido que la Constitución, además de tener un innegable valor político, posee valor jurídico y vincula directamente a todos los miembros de la sociedad estatal.

10. Las normas internacionales, como se ha dicho, constituye un elemento normativo extraño dentro del orden estatal porque ha tenido su origen extra muros, fuera del ámbito estatal. Estas normas internacionales, cuando se incorporan al ordenamiento estatal, el razonamiento es aplicarles el marco teórico normativo mencionado más arriba. De este modo, se procede a intentar ubicarlas en algún lugar dentro de la escala jerárquica. Como la regla de la jerarquía se determina según los medios de producción normativa, esto es, las fuentes formales, del mismo modo, el razonamiento respecto de las normas internacionales sólo dice relación con las fuentes formales, con la consecuente castración de un entendimiento global de los que es el Derecho.

\footnotetext{
${ }^{22}$ Vid. la opinión del Tribunal Constitucional de Moldavia: "In its Resolution No 55 of 14 October 1999, the Constitutional Court ruled on the interdependence of national normative acts and international treaties noting that universally recognised principles and rules of international law were binding on the Republic of Moldova inasmuch as it expressed its consent to abide by them. Consequently, the execution of the rules of the international treaties to which the Republic of Moldova has acceded is unconditional". Constitutional Court of the Republic of Moldova: Acts of the Constitutional Court of the Republic of Moldova, Resolution on the control of constitutionality of the Rome Statute of the International Criminal Court, para. 2. Monitorul Oficial al Republicii Moldova, No 161-164 (30483051) 12 October 2007; Monitorul Oficial al Republicii Moldova, 1999, No 118-119, p. 64.
} 
11. Con todo, es relevante destacar aquí que un principio de derecho internacional general firmemente asentado indica que el Estado tiene el deber de adecuar su derecho interno, sus prácticas administrativas y judiciales a las obligaciones internacionales que ha asumido. Complementa este principio, otro igualmente de derecho internacional general ampliamente reconocido que señala que los Estados no pueden ampararse en su derecho interno, ni siquiera en su Constitución, para justificar el incumplimiento o para liberarse o para eximirse del cumplimiento de sus obligaciones internacionales. Tratándose de los derechos humanos, las obligaciones que surgen de ellos para los Estados son la obligación de respetar, de proteger y de realizarlos plenamente según un principio de progresividad y de expansión.

12. Un ejemplo notable de esta forma de razonamiento jurídico ha sido expresado por los Ministros señores Dolmestch y Künsemüller de la Corte Suprema, en un proceso sobre secuestro permanente ocurrido durante la época de la dictadura donde, además de la acción penal, se ejerció la acción civil destinada a obtener reparación por las consecuencias dañosas derivadas del ilícito. En efecto, estos Ministros han sostenido que:

" $[\mathrm{P}]$ rocede acoger las acciones civiles deducidas en autos, que tienen como objeto obtener la reparación íntegra de los perjuicios ocasionados por el actuar de los agentes del Estado de Chile, ya que así lo demanda la aplicación de buena fe a los tratados internacionales suscritos por nuestro país, así como la interpretación de las normas de derecho internacional consideradas ius cogens por la comunidad jurídica internacional. Por tanto, dichas normas deben tener aplicación preferente en nuestro ordenamiento interno, al tenor de lo que dispone el artículo $5^{\circ}$ de la Constitución Política de la República, por sobre aquellas disposiciones de orden jurídico nacional que posibilitarían eludir las responsabilidades en que ha incurrido el Estado chileno, a través de la actuación penalmente culpable de sus funcionarios, dando cumplimiento de este modo a la Convención de Viena sobre Derecho de los Tratados". ${ }^{23}$

Estos mismos Ministros expresan más adelante en su voto en contra del voto de mayoría relativo al rechazo de la acción reparatoria civil, que:

"[L]os mismos fundamentos enunciados precedentemente permiten desestimar las restantes alegaciones del demandado, en particular la relativa a la excepción

${ }^{23}$ Corte Suprema: Secuestro calificado Jaime Aldoney Vargas. Recurso de Casación. Rol No 4.915-09. Sentencia de fecha 5 de mayo de 2011. Voto en contra del rechazo de la acción civil de los Ministros señores Dolmestch y Künsemüller. Considerando 6º. 
de prescripción de las acciones civiles ejercidas y de inexistencia de una responsabilidad objetiva e imprescriptible por parte del Estado chileno, al emanar de la ley la responsabilidad que se pretende hacer efectiva, siendo aquélla precisamente la de rango constitucional contemplada en el ya citado artículo $5^{\circ}$ de la Constitución, que ha posibilitado la incorporación en el ordenamiento jurídico nacional de las obligaciones contempladas por los instrumentos internacionales que recogen los principios generales del Derecho Humanitario, entre los cuales se encuentra aquélla relativa a la obligación de indemnizar los daños producidos por la violación de los derechos humanos". ${ }^{24}$

13. Una de las vías por las cuales el Estado se asegura de cumplir su deber de adecuar el orden jurídico interno al derecho internacional es mediante la realización efectiva de una función de control. Nos estamos refiriendo al control de convencionalidad que vendría a insertarse dentro del esquema más amplio de control entendido como una de las tareas del Estado. A continuación, abordaremos las distintas formas que ha ido adquiriendo este control de convencionalidad y su materialización concreta.

\section{El control de convencionalidad realizado por los jueces chilenos}

14. Uno de los primeros casos de control de convencionalidad realizados por la justicia chilena -en los términos desarrollados por la Corte Interamericana de Derechos Humanos- se produjo en la sentencia de la Corte Suprema de 2004 relativa al caso del secuestro de Miguel Ángel Sandoval Rodríguez que se ha convertido en un verdadero hito judicial. Esta sentencia se inspira y aplica efectivamente los criterios y estándares fijados por la Corte Interamericana de Derechos Humanos en el caso Barrios Altos. ${ }^{25}$

15. Otra sentencia que refleja un control efectivo de convencionalidad por la Corte Suprema es el caso Molco, de 2006. En este caso la Corte Suprema aplica igualmente el derecho internacional convencional -además de los principios y la costumbre como fuentes del derecho internacional- para resolver el caso. Del mismo modo, se apoya y aplica los criterios y las enseñanzas derivadas de la jurisprudencia de la Corte Interamericana de Derechos Humanos, particularmente, el caso Almonacid y otros vs. Chile, de 2006.

\footnotetext{
${ }^{24}$ Corte Suprema: Secuestro calificado Jaime Aldoney Vargas. Recurso de Casacion. Rol No 4.915-09. Sentencia de fecha 5 de mayo de 2011. Voto en contra del rechazo de la acción civil de los Ministros señores Dolmestch y Künsemüller. Considerando $7^{\circ}$.

${ }^{25}$ Corte IDH: Caso Barrios Altos vs. Perú. Fondo. Sentencia de 14 de marzo de 2001. Serie C No 75.
} 
16. A partir de la práctica realizada por los órganos jurisdiccionales chilenos, particularmente del poder judicial, se podría distinguir el control de convencionalidad explícito y el control de convencionalidad implícito. El control de convencionalidad explícito es aquel en que el juez nacional reconoce y se refiere expresamente a la norma convencional y a la interpretación de autoridad que está utilizando como parámetro de control. En cambio, el control de convencionalidad implícito es aquel en el que el juez nacional efectúa de facto un control de de la norma interna conforme al parámetro de la norma convencional y/o de la interpretación auténtica de la misma, pero no alude expresamente a la norma convencional o a la jurisprudencia internacional que utiliza. Con todo, es preciso advertir que los jueces nacionales no utilizan ni recurren aún al concepto de control de convencionalidad.

\section{i) El control de convencionalidad implícito}

17. La sentencia de la Corte Suprema, en el caso sobre el secuestro calificado de Rudy Cárcamo Ruiz, efectúa a cabalidad un control de convencionalidad de la manera que señala las enseñanzas de la Corte IDH. En este caso, el control de convencionalidad es implícito y explícito a la vez. En esta parte nos referiremos a la forma implícita del control. Así, el control es implícito, en el sentido de que los jueces del máximo tribunal no indican expresamente la jurisprudencia de la Corte IDH en la que basan su argumentación.

18. En efecto, refiriéndose a los límites en el ejercicio del poder y a los elementos básicos compartidos de un Estado de Derecho, en su considerando $11^{\circ}$, la sentencia señala: "Por graves que puedan ser ciertas acciones y por culpables que puedan ser los responsables de determinadas acciones, no es posible admitir que el poder pueda ejercerse sin restricción alguna o que el Estado pueda valerse de cualquier procedimiento para alcanzar sus fines, sin sujeción al derecho o a la moral. En definitiva, ninguna actividad del Estado puede fundarse sobre el desprecio a la dignidad humana" ${ }^{26}$

19. Este parte del razonamiento del tribunal se basa en la sentencia de la Corte IDH pronunciada en el caso Velásquez Rodríguez vs. Honduras de 1988. En este ultimo fallo, la Corte IDH sostiene:

\footnotetext{
${ }^{26}$ Corte Suprema: Secuestro calificado de Rudy Cárcamo Ruiz. Recurso de Casación. Rol No 288-12. Sentencia de fecha 24 de mayo de 2012. Sentencia de Reemplazo. Considerando $11^{\circ}$.
} 
"Está más allá de toda duda que el Estado tiene el derecho y el deber de garantizar su propia seguridad. Tampoco puede discutirse que toda sociedad padece por las infracciones a su orden jurídico. Pero, por graves que puedan ser ciertas acciones y por culpables que puedan ser los reos de determinados delitos, no cabe admitir que el poder pueda ejercerse sin límite alguno o que el Estado pueda valerse de cualquier procedimiento para alcanzar sus objetivos, sin sujeción al derecho o a la moral. Ninguna actividad del Estado puede fundarse sobre el desprecio a la dignidad humana". ${ }^{27}$

20. A continuación, la Corte Suprema, desarrollando su argumentación sobre el tipo penal y los elementos del delito, cuyo es un crimen internacional, afirma que:

"[L]os hechos de la causa, no cabe duda alguna que deben ser subsumidos a la luz del derecho internacional humanitario dentro de la categoría de crímenes contra la humanidad. El secuestro realizado por agentes del Estado -o por un individuo que actúa con autorización, apoyo o aquiescencia oficial-, es un caso de privación de libertad que conculca, además de la libertad ambulatoria, el derecho del detenido a ser llevado sin demora ante un juez y a deducir los recursos apropiados para controlar la legalidad de su 'arresto' y que conlleva el aislamiento prolongado y la incomunicación coactiva de la víctima, la negación de su detención y reclusión a terceros interesados, que representan, por sí mismas, formas de tratamiento cruel e inhumano, lesivas de la integridad síquica y moral y del debido respeto a la dignidad inherente al ser humano; configuran, por tanto, una violación múltiple y continuada de numerosos derechos, que ha sido calificada por la Asamblea de la Organización de Estados Americanos como 'una afrenta a la conciencia del Hemisferio y constituye un crimen de lesa humanidad' (AG/ RES 666), que la comunidad mundial se ha comprometido a erradicar, pues tales hechos merecen una reprobación categórica de la conciencia universal, al atentar contra los valores humanos fundamentales, que ninguna convención, pacto o norma positiva puede derogar, enervar o disimular". ${ }^{28}$

21. En este razonamiento y argumentación de los jueces del máximo tribunal, se retoma básicamente íntegramente las enseñanzas de la Corte IDH,

${ }^{27}$ Corte IDH: Caso Velásquez Rodríguez vs. Honduras. Fondo. Sentencia de 29 de julio de 1988. Serie C No 4, para. 154.

${ }^{28}$ Corte Suprema: Secuestro calificado de Rudy Cárcamo Ruiz. Recurso de Casación. Rol No 288-12. Sentencia de fecha 24 de mayo de 2012. Sentencia de Reemplazo. Considerando $15^{\circ}$. 
desarrolladas en la sentencia Velázquez Rodríguez. En esta sentencia, los jueces interamericanos aseveraron que:

"El secuestro de la persona es un caso de privación arbitraria de libertad que conculca, además, el derecho del detenido a ser llevado sin demora ante un juez y a interponer los recursos adecuados para controlar la legalidad de su arresto $[\ldots] " .{ }^{29}$

"el aislamiento prolongado y la incomunicación coactiva a los que se ve sometida la víctima representan, por sí mismos, formas de tratamiento cruel e inhumano, lesivas de la libertad psíquica y moral de la persona y del derecho de todo detenido al respeto debido a la dignidad inherente al ser humano [...]" ${ }^{30}$

"La desaparición forzada de seres humanos constituye una violación múltiple y continuada de numerosos derechos [...]". ${ }^{31}$

"La Asamblea de la OEA ha afirmado que 'es una afrenta a la conciencia del Hemisferio y constituye un crimen de lesa humanidad' (AG/RES.666) [...]”. ${ }^{32}$

22. Como se puede apreciar, a pesar de que la sentencia no lo dice expresamente, los jueces del máximo tribunal chileno asumen prácticamente en su totalidad, mediante un análisis de convencionalidad, las enseñanzas provenientes de la Corte Interamericana de Derechos Humanos, lo cual, a nuestro juicio, es un paso en la dirección correcta, y que, por lo demás, se corresponde con prácticas judiciales contemporáneas realizadas por jurisdicciones extranjeras.

23. En efecto, por ejemplo, en Guatemala, la Cámara Penal de la Corte Suprema de Justicia ha declarado "la autoejecutabilidad de sentencias de casos presentados por la CIDH ante la Corte Interamericana de Derechos Humanos, entre ellos 'Niños de la Calle (Villagrán Morales y otros)'; 'Panel Blanca (Paniagua Morales y otros)'; 'Bámaca Velásquez'; 'Carpio Nicolle y otros'; 'Masacre de las Dos Erres' y, ha ordenado que el Ministerio Público realice nuevas investigaciones para determinar a los responsables materiales e intelectuales de

\footnotetext{
${ }^{29}$ Corte IDH: Caso Velásquez Rodríguez vs. Honduras. Fondo. Sentencia de 29 de julio de 1988. Serie C No 4, para. 155.

${ }^{30}$ Corte IDH: Caso Velásquez Rodríguez vs. Honduras. Fondo. Sentencia de 29 de julio de 1988. Serie C No 4, para. 156.

${ }^{31}$ Corte IDH: Caso Velásquez Rodríguez vs. Honduras. Fondo. Sentencia de 29 de julio de 1988. Serie C No 4, para. 155.

${ }^{32}$ Corte IDH: Caso Velásquez Rodríguez vs. Honduras. Fondo. Sentencia de 29 de julio de 1988. Serie C No 4, para. 153.
} 
las violaciones a los derechos humanos establecidas por la Corte IDH en las respectivas sentencias". ${ }^{33}$

24. Por último, la Corte Suprema chilena, en el caso sobre el secuestro calificado de Rudy Cárcamo Ruiz, efectúa un control de convencionalidad también implícito, cuando considera la interpretación de la Corte Interamericana de Derechos Humanos, en el párrafo siguiente:

“[...] en armonía con ello y en vista de la evolución del derecho internacional de los derechos humanos, los hechos sobre los que versa este litigio son imprescriptibles, desde que es obligatoria para el derecho chileno la normativa del Derecho Internacional Penal de los Derechos Humanos para el cual es inadmisible la prescripción que pretenda imposibilitar la investigación de violaciones graves de los derechos humanos y la sanción, en su caso, de los responsables". ${ }^{34}$

25. En el pasaje anterior, la Corte Suprema asume la jurisprudencia de la Corte IDH, si bien no literalmente, al menos asume el principio general sentado por las enseñanzas interamericanas y, en este contexto, cumple plenamente con lo señalado por el fallo de la Corte IDH en el caso Atala, cuando dicha sentencia afirma que "es necesario que las interpretaciones judiciales y administrativas y las garantías judiciales se apliquen adecuándose a los principios establecidos en la jurisprudencia de este Tribunal". ${ }^{35}$ Es generalmente conocido que las bases esenciales de esta jurisprudencia interamericana fueron establecidas por la Corte IDH en los casos Barrios Altos, La Cantuta y Almonacid Arellano. ${ }^{36}$

\section{ii) El control de convencionalidad explícito}

26. Como se dijo anteriormente, la sentencia de la Corte Suprema, en el caso sobre el secuestro calificado de Rudy Cárcamo Ruiz, también efectúa un

\footnotetext{
${ }^{33} \mathrm{CIDH}$ valora avances contra la impunidad en Guatemala y expresa preocupación por la situación de derechos humanos de los pueblos indígenas y las mujeres. Comunicado de Prensa No 33/12, 27 de marzo de 2012.

${ }^{34}$ Corte Suprema: Secuestro calificado de Rudy Cárcamo Ruiz. Recurso de Casación. Rol No 288-12. Sentencia de fecha 24 de mayo de 2012. Considerando $34^{\circ}$.

${ }^{35}$ Corte IDH: Caso Atala Riffo y Niñas vs. Chile. Fondo, Reparaciones y Costas. Sentencia del 24 de febrero de 2012. Serie C No 239, para. 284.

${ }^{36}$ Corte IDH: Caso Barrios Altos vs. Perú. Fondo. Sentencia de 14 de marzo de 2001. Serie C No 75; Corte IDH: Caso La Cantuta vs. Perú. Fondo, Reparaciones y Costas. Sentencia de 29 de noviembre de 2006. Serie C No 162; Corte IDH: Caso Almonacid Arellano y otros vs. Chile. Excepciones Preliminares, Fondo, Reparaciones y Costas. Sentencia de 26 de septiembre de 2006. Serie C No 154.
} 
control explícito de convencionalidad respecto de los cuatro Convenios de Ginebra.

27. En este sentido, refiriéndose al ámbito de aplicación de los "Convenios de Ginebra de mil novecientos cuarenta y nueve, ratificados por Chile mediante Decreto Supremo No 752, de cinco de diciembre de mil novecientos cincuenta, publicados en el Diario Oficial de diecisiete, dieciocho, diecinueve y veinte de abril del año siguiente", la Corte Suprema expresa que "[e]xcepcionalmente, se emplean en caso de 'conflicto armado sin carácter de internacional', conforme a lo prevenido en el artículo $3^{\circ}$ común para todos los Convenios de Ginebra, dado que 'por útiles que sean, pues, las diversas condiciones antes enunciadas, no son indispensables, ya que ningún Gobierno puede sentirse molesto por respetar, en la confrontación con sus adversarios internos y sea cual fuere la denominación del conflicto que lo opone a ellos, un mínimo de normas que respeta de hecho todos los días, en virtud de sus propias leyes, e incluso en el trato de vulgares criminales de derecho común'. Refuerza lo anterior que el propósito de dichos Convenios es exclusivamente humanitario y que sólo garantiza el respeto mínimo de normas que los pueblos civilizados consideran como válidas en todas partes y circunstancias, por estar por encima y fuera incluso de confrontaciones bélicas, y cuya observancia no está subordinada a deliberaciones preliminares sobre la índole del conflicto o de las disposiciones particulares que han de respetarse. Lo contrario sería pretender que en casos de disturbios internos que el gobierno de turno calificara, con justo motivo, de simples actos de bandidaje y dado que el artículo $3^{\circ}$ en examen no es aplicable, aquel tiene derecho a dejar a los heridos sin asistencia, a infligir torturas o mutilaciones o a realizar ejecuciones sumarias". ${ }^{37}$

28. Este control de convencionalidad, en este caso de la convencionalidad de los Convenios de Ginebra de 1949, y singularmente de su artículo $3^{\circ}$, tiene dos características que nos parece relevante resaltar. Por un lado, se trata de un control de convencionalidad explícito, aun cuando no se utiliza la noción de control de convencionalidad. Por otro lado, este control de convencionalidad es tanto más destacable por cuanto demuestra que el horizonte de dicho control es mucho más extenso que la sola mirada reduccionista del control de convencionalidad referido a la Convención Americana sobre Derechos Humanos y a la interpretación de la Corte IDH.

37 Corte Suprema: Secuestro calificado de Rudy Cárcamo Ruiz. Recurso de Casación. Rol No 288-12. Sentencia de fecha 24 de mayo de 2012. Sentencia de Reemplazo. Considerando $8^{\circ}$. 
29. Asimismo, es posible encontrar otros ejemplos de un control de convencionalidad explícito en la práctica judicial chilena. Así, en una sentencia de la Corte de Apelaciones de Valdivia pronunciada en mayo de 2012 con ocasión de un recurso de protección, a propósito de una tala ilegal de "árboles milenarios que constituyen el cordón de protección y parte esencial del Ngen Mapu Quintuante, espíritu que es parte de la cosmovisión religiosa de la comunidad Mapuche-Williche" en el que hacen regularmente ceremonias tradicionales, se ejerció un control explícito de convencionalidad.

30. En efecto, los recurrentes, pertenecientes a la comunidad MapucheWilliche, alegan que el dueño del predio efectúa una tala ilegal de árboles milenarios (complejo religioso y ceremonial) y que son parte esencial del Ngen Mapu Quintuante, lo que impide el normal desarrollo de las manifestaciones religiosas y espirituales mapuches; que el dueño del predio no les permite el libre acceso al Ngen Mapu Quintuante para ejercer sus actividades religiosas. Agregan que la tala es, además, arbitraria ya que se realiza con el fin de "afectar el entorno del Ngen Mantu Quintuante, para acabar con él y hostigar a la comunidad mapuche-huilliche que participa en su defensa". Los recurrentes expresan adicionalmente que "Expresan que la estrecha relación que los mapuche-williche mantienen con la madre tierra (ñuke mapu) debe ser comprendida como la base fundamental de su cultura, vida espiritual, integridad y supervivencia económica y que por ello la intervención del río y en particular del centro ceremonial es un grave perjuicio y su deber como pueblo es impedirlo". ${ }^{38}$

31. Los derechos humanos que se estiman vulnerados son el derecho a la libertad de conciencia, la manifestación de todas las creencias y el ejercicio libre de todos los cultos (artículo 19 No 6 de la Constitución). El acto violatorio que se señala choca con el deber de protección de los sitios ceremoniales mapuches el cual se enlaza con el deber de protección de las culturas indígenas y del deber de promover y resguardar las manifestaciones culturales indígenas. Estas obligaciones se encuentran expresadas en la Ley No 19.253 complementadas con el Convenio No 169 de la Organización Internacional del Trabajo de 1989, debidamente ratificado por Chile, "que tiene la calidad de tratado internacional de derechos humanos entrando a formar parte de la

\footnotetext{
${ }^{38}$ Corte de Apelaciones de Valdivia: Millaray Virginia Huichalaf Pradines y otros contra Juan Heriberto Ortiz Ortiz. Recurso de Protección, Rol No 501-2011. Sentencia de fecha 4 mayo de 2012. Considerando $2^{\circ}$.
} 
Constitución Chilena por aplicación del artículo 5 inciso $2^{\circ}$ de dicha Carta Fundamental". ${ }^{39}$

32. Además, los recurrentes alegan que el acto denunciado vulnera la garantía constitucional de vivir en un medio ambiente libre de contaminación (artículo 19 No 8 de la Constitución), fundado en que es deber del Estado, velar porque este derecho no se vea afectado y tutelar la protección de la naturaleza. Los recurrentes precisan que "como consecuencia de la tala ilegal de las especies nativas que forman parte [...] del espacio tradicional en donde habita el Ngen Mapu Quintuante, se produce también una grave afectación en el plano socio cultural de los derechos de las comunidades mapuche williche pues una serie de manifestaciones de su cultura tienen relación con la tierra y con el lugar donde se realizan estas, afectándose el medio ambiente en el sentido preciso que señala en el artículo $1^{\circ}$ letra ll de la Ley de Bases del Medio Ambiente, el cual entiende como un sistema global, inclusivo de los elementos socio culturales y sus interacciones". ${ }^{40}$ Este análisis se ve complementada por el artículo 13.1 del Convenio No169 de la Organización Internacional del Trabajo de 1989, por el artículo 25 de la Declaración de las Naciones Unidas sobre Derechos de los Pueblos Indígenas, aprobado por la Asamblea General de Naciones Unidas el año 2007, y por el artículo $8^{\circ}$ del Convenio sobre la diversidad Biológica de 1992. ${ }^{41}$

33. El razonamiento de la Corte de apelaciones de Valdivia se centra en la vulneración de la libertad de conciencia, la manifestación de todas las creencias y el ejercicio libre de todos los cultos (artículo 19 No 6 de la Constitución). La Corte de Apelaciones complementa largamente el contenido y alcance de esta libertad con el Convenio No169 de la Organización Internacional del Trabajo de 1989, que desde el 15 de septiembre de 2009, se encuentra vigente en nuestro país, y que contiene el estándar mínimo para el ejercicio de los derechos fundamentales de los pueblos indígenas. La Corte se enfoca en las

\footnotetext{
${ }^{39}$ Corte de Apelaciones de Valdivia: Millaray Virginia Huichalaf Pradines y otros contra Juan Heriberto Ortíz Ortíz. Recurso de Protección, Rol No 501-2011. Sentencia de fecha 4 mayo de 2012. Considerando $4^{\circ}$.

${ }^{40}$ Corte de Apelaciones de Valdivia: Millaray Virginia Huichalaf Pradines y otros contra Juan Heriberto Ortiz Ortiz. Recurso de Protección, Rol No 501-2011. Sentencia de fecha 4 mayo de 2012. Considerando $5^{\circ}$.

${ }^{41}$ Chile ratificó el Convenio sobre la Diversidad Biológica el 9 de septiembre de 1994, mediante Decreto Supremo No 1.963 del Ministerio de Relaciones Exteriores, el que fue publicado en el Diario Oficial con fecha 6 de mayo de 1995.
} 
obligaciones vinculadas con el respeto de la cultura y los valores espirituales de los pueblos indígenas así como la importancia de relación con la tierra o su territorio, derivadas del artículo $2^{\circ}, 4^{\circ}, 5^{\circ}$ y 13 del referido Convenio Internacional.

34. Como se ha apreciado, la Corte de Apelaciones de Valdivia, realiza explícitamente en esta sentencia un acto de control de cumplimiento y de satisfacción de los estándares de protección de los derechos humanos fijados en el Convenio No 169 de la Organización Internacional del Trabajo de 1989. Pero, además, la Corte de Apelaciones aplica e incorpora, al momento de efectuar la estimación de la convencionalidad, la jurisprudencia pertinente de la Corte Interamericana de Derechos Humanos, en particular, el caso Comunidad Sawhoyamaxa vs. Paraguay, de 2006. Este es un caso concreto de incorporación en la práctica judicial chilena de la interpretación proporcionada por los jueces interamericanos, en este caso, a propósito de la cosmovision indígena, su religiosidad, su especial relación con la tierra y su identidad cultural. La Corte de Apelaciones de Valdivia expresa que:

"[Ú]til es consignar además, que la Corte Interamericana de Derechos Humanos en el caso Comunidad Sawhoyamaxa contra el estado de Paraguay, señala que la cultura de los pueblos indígenas corresponde a una forma de vida particular de ser, ver y actuar en el mundo, constituido a partir de su estrecha relación con sus tierras tradicionales y recursos naturales, no solo por ser estos su principal medio de subsistencia, sino además, porque constituyen un elemento integrante de su cosmovisión, religiosidad y por ende su identidad cultural". ${ }^{42}$

35, En esta argumentación, la Corte de Apelaciones asume e incorpora los estándares y criterios de derechos humanos fijados en las sentencias de la Corte Interamericana de Derechos Humanos, en una esfera tan rica jurídicamente hablando como es la protección de la identidad cultural indígena. Entre las sentencias en donde la Corte Interamericana de Derechos Humanos ha fijado estos estándares están el caso Comunidad Indígena Yakye Axa vs. Paraguay de 2005 y el caso Comunidad Indigena Sawhoyamaxa vs. Paraguay de 2006.

"Haciendo uso de los criterios señalados, este Tribunal ha considerado que la estrecha vinculación de los integrantes de los pueblos indígenas con sus tierras

${ }^{42}$ Corte de Apelaciones de Valdivia: Millaray Virginia Huichalaf Pradines y otros contra Juan Heriberto Ortiz Ortiz. Recurso de Protección, Rol No 501-2011. Sentencia de fecha 4 mayo de 2012. Considerando $14^{\circ}$. 
tradicionales y los recursos naturales ligados a su cultura que ahí se encuentren, así como los elementos incorporales que se desprendan de ellos, deben ser salvaguardados por el artículo 21 de la Convención Americana. La cultura de los miembros de las comunidades indígenas corresponde a una forma de vida particular de ser, ver y actuar en el mundo, constituido a partir de su estrecha relación con sus tierras tradicionales y recursos naturales, no sólo por ser estos su principal medio de subsistencia, sino además porque constituyen un elemento integrante de su cosmovisión, religiosidad y, por ende, de su identidad cultural". ${ }^{43}$

36. En este contexto, "habiéndose dado por acreditado la efectividad de corte de bosque nativo, sin autorización de Conaf, en territorio sagrado para la comunidad mapuche wiilliche", la Corte de Apelaciones considera vulnerado el artículo 19 No6 de la Constitución y el Convenio No 169 de la Organización Internacional del Trabajo de 1989 "que considera elemental respetar la cosmovisión de los pueblo indígenas, que incluye su forma de manifestar su religiosidad”. ${ }^{44}$ En su decisión final, la Corte ordena al recurrido "cesar en sus actividades de tala ilegal de árboles milenarios que se encuentra en un terreno de 2,5 hectáreas de su predio Hijuela No 3 de Carimallin, y permitir el libre acceso de los recurrentes a dicho sitio, que es un lugar sagrado para la comunidad Mapuche Williche, del sector Maihue Carimallin, en la época estival y para el solo efecto de realizar rogativas de Lepun y Nguillatun”.

\section{Examen de convencionalidad, proceso de humanización del derecho y conciencia jurídica universal}

37. Por último, y quizás el aspecto más relevante del examen de convencionalidad realizado por la Corte Suprema en la sentencia en comento, es la afirmación que pone fin a una época y que abre la puerta al inicio de una nueva, incorporando a la Corte Suprema en la senda de un nuevo Derecho. Este

43 Corte IDH: Caso Comunidad Indígena Yakye Axa vs. Paraguay. Fondo Reparaciones y Costas. Sentencia 17 de junio de 2005. Serie C No 125, para. 135; Corte IDH: Caso Comunidad Indígena Sawhoyamaxa vs. Paraguay. Fondo, Reparaciones y Costas. Sentencia de 29 de marzo de 2006. Serie C No 146, para. 118.

${ }^{44}$ Corte de Apelaciones de Valdivia: Millaray Virginia Huichalaf Pradines y otros contra Juan Heriberto Ortiz Ortiz. Recurso de Protección, Rol No 501-2011. Sentencia de fecha 4 mayo de 2012. Considerando $15^{\circ}$. 
verdadero cambio de paradigma, alguna de cuyas luces ya habíamos detectado con anterioridad, ${ }^{45}$ es expresado por la Corte Suprema de la siguiente forma:

"[A]tendida la naturaleza del hecho pesquisado y con arreglo a los antecedentes reunidos durante la indagación, es procedente inferir que se está en presencia de lo que la conciencia jurídica universal ha dado en denominar delito contra la humanidad". 46

La desaparición forzada de personas configura "una afrenta a la conciencia del Hemisferio y constituye un crimen de lesa humanidad, que la comunidad mundial se ha comprometido a erradicar, pues tales hechos merecen una reprobación categórica de la conciencia universal, al atentar contra los valores humanos fundamentales, que ninguna convención, pacto o norma positiva puede derogar, enervar o disimular". ${ }^{47}$

"[E]n la medida que los acontecimientos pesquisados configuran crímenes contra la humanidad, de ellos deviene como lógico corolario la inexorabilidad de su juzgamiento y su consiguiente imprescriptibilidad, desde que los ilícitos contra la humanidad son delitos contra el derecho de gentes que la comunidad mundial se ha comprometido a erradicar". ${ }^{48}$

38. En esta parte, también la Corte Suprema se ha nutrido, a nuestro modo de ver, de las valiosas enseñanzas provenientes de la Corte Interamericana de Derechos Humanos y de los votos individuales de sus integrantes, lo que nos lanza de lleno en la era de un constitucionalismo -en tanto protección de los derechos humanos- de diversos niveles.

39. En efecto, esta idea de la conciencia jurídica universal como la fuente última de todo el Derecho, se encuentra presente, por ejemplo, en la Opinión Consultiva sobre la Condición Jurídica y Derechos de los Migrantes Indocumentados de 2003 de la Corte Interamericana de Derechos Humanos:

"Además, [el señalamiento de algunos ejemplos] permiten a esta Corte mostrar que su Opinión Consultiva no constituye una mera especulación académica

\footnotetext{
${ }^{45}$ Aguilar Cavallo, Gonzalo: "Hacia un sistema integral de derechos humanos: Comentario a la sentencia del tribunal constitucional chileno 'Sobre la píldora del día después”, en Revista Ius et Praxis, año 14, núm. 1, 2008, pp. 347-362.

${ }^{46}$ Corte Suprema: Secuestro calificado de Rudy Cárcamo Ruiz. Recurso de Casación. Rol No 288-12. Sentencia de fecha 24 de mayo de 2012. Sentencia de Reemplazo. Considerando $14^{\circ}$.

${ }^{47}$ Corte Suprema: Secuestro calificado de Rudy Cárcamo Ruiz. Recurso de Casación. Rol No 288-12. Sentencia de fecha 24 de mayo de 2012. Sentencia de Reemplazo. Considerando $15^{\circ}$.

48 Corte Suprema: Secuestro calificado de Rudy Cárcamo Ruiz. Recurso de Casación. Rol No 288-12. Sentencia de fecha 24 de mayo de 2012. Sentencia de Reemplazo. Considerando $16^{\circ}$.
} 
y que el interés en la misma se justifica por el beneficio que pueda traer a la protección internacional de los derechos humanos y al fortalecimiento de la conciencia jurídica universal”. ${ }^{49}$

40. Junto con esto, los votos individuales de algunos de los jueces interamericanos claramente han servido de sustento material para el razonamiento e interpretación jurídica desarrollados por la Corte Suprema en el caso en comento. En este sentido, mencionaremos algunas de las enseñanzas que se desprenden de estos votos individuales y cuya presencia se puede observar en la sentencia de la Corte Suprema:

"Las propias emergencia y consolidación del corpus juris del Derecho Internacional de los Derechos Humanos se deben a la reacción de la conciencia jurídica universal ante los recurrentes abusos cometidos contra los seres humanos, frecuentemente convalidados por la ley positiva: con esto, el Derecho vino al encuentro del ser humano, destinatario último de sus normas de protección”. ${ }^{50}$

"Con la desmitificación de los postulados del positivismo voluntarista, se tornó evidente que sólo se puede encontrar una respuesta al problema de los fundamentos y de la validez del derecho internacional general en la conciencia jurídica universal, a partir de la aserción de la idea de una justicia objetiva. Como una manifestación de esta última, se han afirmado los derechos del ser humano, emanados directamente del derecho internacional, y no sometidos, por lo tanto, a las vicisitudes del derecho interno". ${ }^{51}$

"[...] en el dominio del Derecho Internacional de los Derechos Humanos, movido por consideraciones de ordre public internacional, estamos ante valores comunes y superiores, verdaderamente fundamentales e irreductibles, captados por la conciencia humana. Esta última encuéntrase siempre presente, ha acompañado e impulsado toda la evolución del jus gentium, del cual -tengo la plena convicción- es la fuente material por excelencia”. ${ }^{52}$

\footnotetext{
49 Corte IDH: Condición Jurídica y Derechos de los Migrantes Indocumentados. Opinión Consultiva OC-18/03 del 17 de septiembre de 2003. Serie A No 18, para. 65.

${ }^{50}$ Corte IDH. El Derecho a la Información sobre la Asistencia Consular en el Marco de las Garantías del Debido Proceso Legal. Opinión Consultiva OC-16/99 del 1 de octubre de 1999. Serie A No 16. Voto concurrente del juez A. A. Cançado Trindade, para. 4.

${ }^{51}$ Corte IDH. El Derecho a la Información sobre la Asistencia Consular en el Marco de las Garantías del Debido Proceso Legal. Opinión Consultiva OC-16/99 del 1 de octubre de 1999. Serie A No 16. Voto concurrente del juez A. A. Cançado Trindade, para. 14.

${ }^{52}$ Corte IDH: Condición Jurídica y Derechos Humanos del Niño. Opinión Consultiva OC-17/02 del 28 de agosto de 2002. Serie A No 17. Voto concurrente del juez A. A. Cançado Trindade, para. 68.
} 
"A la responsabilidad internacional objetiva de los Estados corresponde necesariamente la noción de ilegalidad objetiva (uno de los elementos subyacentes al concepto de jus cogens). En nuestros días, nadie osaría negar la ilegalidad objetiva de actos de genocidio, de prácticas sistemáticas de tortura, de ejecuciones sumarias y extra-legales, y de desaparición forzada de personas, -prácticas éstas que representan crímenes de lesa-humanidad-, condenadas por la conciencia jurídica universal, a la par de la aplicación de tratados". ${ }^{53}$

"No hay que olvidarse jamás que el Estado fue originalmente concebido para la realización del bien común. El Estado existe para el ser humano, y no viceversa. Ningún Estado puede considerarse por encima del Derecho, cuyas normas tienen por destinatarios últimos los seres humanos. [...] Hay que decirlo y repetirlo con firmeza, cuantas veces sea necesario: en el dominio del Derecho Internacional de los Derechos Humanos, las llamadas 'leyes' de autoamnistía no son verdaderamente leyes: no son nada más que una aberración, una afrenta inadmisible a la conciencia jurídica de la humanidad". ${ }^{54}$

41. Con esta posición, adoptada por la Corte Suprema en el caso denominado Episodio Rudy Cárcamo Ruiz de fecha 24 mayo de 2012, ha quedado en evidencia que la visión únicamente centrada en el aspecto formal de las fuentes positivas no refleja la integralidad del fenómeno jurídico que debe ser analizado, y que, por tanto, es necesario tomar en consideración el reconocimiento universal de ciertos valores fundamentales, sobre la base de un sentido de justicia objetiva, que han contribuido esencialmente a la formación de la opinio juris communis. ${ }^{55}$ La visión positivista del derecho es necesaria, pero incompleta e insuficiente y no da cuenta de la globalidad del fenómeno jurídico actual determinado por una era de globalización y de diálogo jurisprudencial multinivel. El enfoque positivista debe ser necesariamente complementado y completado con un análisis global del Derecho, incorporando la totalidad de las fuentes, y centrándose en el análisis jurídico fundamentalmente en la fuente material y particularmente en la fuente última de todo el derecho, el ser humano, la propia comunidad, y su convicción jurídica y conciencia del derecho.

\footnotetext{
53 Corte IDH: Condición Jurídica y Derechos de los Migrantes Indocumentados. Opinión Consultiva OC-18/03 del 17 de septiembre de 2003. Serie A No 18. Voto concurrente del juez A. A. Cançado Trindade, para. 71.

${ }^{54}$ Corte IDH: Caso Barrios Altos vs. Perú. Fondo. Sentencia de 14 de marzo de 2001. Serie C No 75. Voto concurrente del juez A. A. Cançado Trindade, para. 26.

55 Corte IDH: Condición Jurídica y Derechos de los Migrantes Indocumentados. Opinión Consultiva OC-18/03 del 17 de septiembre de 2003. Serie A No 18. Voto concurrente del juez A. A. Cançado Trindade, para. 26.
} 


\section{E. Estado de Derecho y control de convencionalidad}

42. Los Estados reunidos en la Asamblea General de la Organización de las Naciones Unidas han reconocido "la importancia de que se restablezca la confianza en el estado de derecho como elemento fundamental de la justicia de transición". ${ }^{56}$ El Estado de Derecho es, por tanto, un concepto que no sólo se encuentra presente en el orden interno de los Estados, sino también en la esfera internacional. El derecho de los derechos humanos, el derecho internacional penal, el derecho de los refugiados y el derecho humanitario son algunas de las disciplinas que han ayudado a establecer los estándares básicos tanto del Estado de Derecho interno como internacional, los cuales tienden a homologarse. En este sentido, el Estado de Derecho contemporáneo, multidimensional, sería el reflejo de un imperativo de orden público, el cual implicaría el reconocimiento de que los derechos humanos constituyen el fundamento básico del ordenamiento jurídico. ${ }^{57}$

43. En este último sentido, la sentencia de 2012 de la Corte Suprema chilena en el caso del secuestro calificado de Rudy Cárcamo Ruíz -en el contexto de las violaciones a los derechos humanos ocurridas durante la dictadura militar- implicaría un paso adelante en el proceso de restablecimiento de la confianza en el Estado de Derecho en Chile. Esta sentencia no sólo considera improcedente el Decreto Ley de Amnistía de 1978 sino que además descarta la aplicación de la prescripción penal -incluso de la prescripción gradualprevista en el artículo 103 del Código Penal chileno, en virtud de lo dispuesto en el derecho internacional, singularmente en el derecho humanitario y en el derecho de los derechos humanos.

Otra sentencia de similares características, de junio de 2012 en el caso del secuestro calificado de Héctor Vergara Doxrud, expresa claramente el criterio fundamental antes mencionado, señalando que:

\footnotetext{
${ }^{56}$ Asamblea General: El estado de derecho en los planos nacional e internacional. Doc. N.U. A/ RES/66/102, 9 de diciembre de 2011, para. 10.

57 "Es este un imperativo de ordre public internacional, que implica el reconocimiento de que los derechos humanos constituyen el fundamento básico, ellos propios, del ordenamiento jurídico. Y los valores, que le son siempre subyacentes, -además de perfectamente identificables- cuidan de darles expresión concreta. No hay que pasar desapercibido, por ejemplo, que ya el preámbulo de la Declaración Universal de los Derechos Humanos de 1948 invocaba la 'conciencia de la humanidad'". Corte IDH: Condición Jurídica y Derechos Humanos del Niño. Opinión Consultiva OC-17/02 del 28 de agosto de 2002. Serie A No 17. Voto concurrente del juez A. A. Cançado Trindade, para. 67.
} 
“[...] en vista de la evolución del derecho internacional de los derechos humanos, los hechos sobre los que versa este litigio son imprescriptibles, desde que es obligatoria para el derecho chileno la normativa del Derecho Internacional Penal de los Derechos Humanos, para la cual es inadmisible la prescripción que pretenda imposibilitar la investigación de violaciones graves de los derechos humanos y la sanción, en su caso, de los responsables, todo lo cual también se extiende para efectos de estimar improcedente la media prescripción del artículo 103 del Código Penal". ${ }^{58}$

En este contexto, se ha entendido que " $[\mathrm{p}]$ retender amnistiar los responsables por la perpetración de dichos crímenes de Estado es una afrenta al Estado de Derecho en una sociedad democrática" ${ }^{59}$ y que las leyes de autoamnistía son un atentado en contra del propio Estado de Derecho y "[...] dichas leyes afectan derechos inderogables -el minimum universalmente reconocido-que recaen en el ámbito del jus cogens" ${ }^{60} \mathrm{Al}$ mismo tiempo, el fallo referido asume la preeminencia del derecho convencional americano y de su jurisprudencia, por lo que se presenta como un virtual ejemplo de control de convencionalidad. ${ }^{61}$

44. En armonía con los desarrollos jurisprudenciales en Chile, el juez Cançado Trindade expresó en 2009, en su Opinión Disidente en el asunto de las cuestiones relativas a la obligación de juzgar o extraditar, que:

"[...] the right to be preserved -the right to the realization of justice- is ineluctably linked to the rule of law at both national and international levels. Significantly, due to the awakening of the universal juridical conscience, the matter is nowadays being considered at both levels $[\ldots] "{ }^{62}$

45. La interacción e interdependencia entre el Estado de Derecho en el plano nacional e internacional es notable. Ambos niveles de constituciona-

\footnotetext{
${ }^{58}$ Corte Suprema: Secuestro calificado de Héctor Vergara Doxrud. Recurso de Casación. Rol No 12.566-11. Sentencia de fecha 18 de junio de 2012. Considerando $15^{\circ}$.

59 Corte IDH: Caso Almonacid Arellano y otros vs. Chile. Excepciones Preliminares, Fondo, Reparaciones y Costas. Sentencia de 26 de septiembre de 2006. Serie C No 154 . Voto razonado del juez A. A. Cançado Trindade, para. 15.

${ }^{60}$ Corte IDH: Caso Barrios Altos vs. Perú. Fondo. Sentencia de 14 de marzo de 2001. Serie C No 75. Voto concurrente del juez A. A. Cançado Trindade, para. 10.

${ }^{61}$ Corte Suprema de Chile: Secuestro de Rudy Cárcamo Ruiz. Recurso de Casación. Rol No 288-12. Sentencia de fecha 24 de mayo de 2012.

${ }^{62}$ Vid. Questions relating to the Obligation to Prosecute or Extradite (Belgium v. Senegal), Provisional Measures, Order of 28 May 2009, I.C.J. Reports 2009, p. 139. Dissenting Opinion of Judge Cançado Trindade, p. 199, para. 101.
} 
lización del derecho -en el sentido de poner al centro de sus principios, los derechos humanos, el Estado de Derecho y la democracia- se alimentan y se enriquecen mutuamente. La ausencia de desarrollo o la debilidad de un nivel del Estado de Derecho, fragiliza y dificulta el desempeño del otro. Por esta razón, " $[\mathrm{t}$ ]odos los Estados Miembros deben velar por que su legislación interna esté de acuerdo con sus obligaciones internacionales, cuando sea necesario. Su omisión en tal sentido, ya sea como consecuencia de la falta de voluntad política o de la falta de capacidad, socava el estado de derecho en los planos nacional e internacional". ${ }^{63}$

46. En el ámbito doméstico, y desde un punto de vista conceptual, Cea define el Estado de Derecho como "aquella Nación-Estado o Estado-Sociedad en que impera un sistema jurídico justo, cuya aplicación es objetiva e impersonal, igualmente vinculante para gobernantes y gobernados y en el que, por lo mismo, ninguna arbitrariedad queda ni puede resultar sin sanción. En él, el poder o soberanía se hallan sometidos al Derecho". ${ }^{64}$

47. En este sentido se ha manifestado la Corte Suprema de Chile a propósito del ejercicio del poder estatal en su función de mantenimiento del orden público. En su sentencia relativa al caso de los Miembros de la Comunidad Mapuche Wente Winkul Mapu, de 2012, los jueces supremos recordaron las crecientes limitaciones del poder, al sostener:

"Que si bien es cierto y conforme a la normativa aplicable a Carabineros de Chile, dicha institución con el fin de mantener a resguardo el orden y seguridad puede emplear distintos medios para disuadir conductas que vulneren el normal orden social, no es menos cierto que tal uso de la fuerza pública debe ser prudente, racional y proporcional, de forma tal que no pude afectar viviendas particulares inmotivadamente, debiendo abstenerse de usar fuerzas desmedidas que puedan causar daños a sus moradores y en particular a personas en situación de vulnerabilidad que ahí se encuentren, más aún si no hay evidencia concreta que desde tales residencias se hayan estado realizando actos de violencia en su contra. Lo anterior importa que Carabineros de Chile en el cumplimiento de su deber no debe ni puede usar medidas que resulten desproporcionadas e impliquen reprimir

${ }^{63}$ Asamblea General: Informe anual sobre el fortalecimiento y la coordinación de las actividades de las Naciones Unidas orientadas a la promoción del estado de derecho. Informe del Secretario General. Doc. N.U. A/64/298, 17 de agosto de 2009, para. 31.

${ }^{64}$ Cea, José Luis: Derecho Constitucional Chileno. Tomo I. Santiago de Chile: Ediciones Universidad Católica de Chile, 2a edición, 2008, p. 238. 
a quienes no se encuentran participando de los hechos delictivos denunciados que se pretenden controlar". ${ }^{65}$

48. La jurisprudencia chilena ha abordado las bases conceptuales del Estado de Derecho. Así, ha sostenido que "el Estado de Derecho de una Nación consiste en que todas las autoridades públicas y todos los particulares deben someter su acción a la Constitución y a las normas dictadas conforme a ella. De manera que en esta escala gradual si la norma inferior no se ajusta a la norma jurídica de mayor rango, carecerá de valor, fuerza y eficacia jurídica". ${ }^{66}$

49. Por su parte, desde el punto de vista de la jurisprudencia internacional, en su Opinión Consultiva relativa al Habeas Corpus Bajo Suspensión de Garantías, la Corte IDH comenzó a forjar la doctrina del Estado de Derecho interamericano. En la referida Opinión sostuvo que:

"El concepto de derechos y libertades y, por ende, el de sus garantías, es también inseparable del sistema de valores y principios que lo inspira. En una sociedad democrática los derechos y libertades inherentes a la persona, sus garantías y el Estado de Derecho constituyen una tríada, cada uno de cuyos componentes se define, completa y adquiere sentido en función de los otros". ${ }^{67}$

50. La Corte Interamericana de Derechos Humanos complementó lo expresado precedentemente en una nueva Opinión Consultiva relativa a las Garantías Judiciales en Estados de Emergencia. En dicha Opinión, la Corte afirmó:

"Así entendidas, las 'garantías [...] que se derivan de la forma democrática de gobierno', a que se refiere el artículo 29. c), no implican solamente una determinada organización política contra la cual es ilegítimo atentar, sino la necesidad de que ella esté amparada por las garantías judiciales que resulten indispensables para el control de legalidad de las medidas tomadas en situación de emergencia, de manera que se preserve el Estado de Derecho". ${ }^{68}$

\footnotetext{
${ }^{65}$ Corte Suprema de Chile: Caso de Miembros de la comunidad mapuche Wente Winkul Mapu. Recurso de Protección. Rol No 12.558-2011. Sentencia de fecha 3 de abril de 2012. Considerando $8^{\circ}$.

${ }^{66}$ Corte de Apelaciones de Santiago: Sentencia de fecha 16 de enero de 1991. Considerando 5o. En Revista de Derecho y Jurisprudencia, LXXXVIII, 2º, P.S. II, p. 14.

${ }^{67}$ Corte IDH: El Hábeas Corpus Bajo Suspensión de Garantías (arts. 27.2, 25.1 y 7.6 Convención Americana sobre Derechos Humanos). Opinión Consultiva OC-8/87 del 30 de enero de 1987. Serie A No 8, para. 26.

${ }^{68}$ Corte IDH: Garantías Judiciales en Estados de Emergencia (arts. 27.2, 25 y $8^{\circ}$ Convención Americana sobre Derechos Humanos). Opinión Consultiva OC-9/87 del 6 de octubre de 1987. Serie A No 9, para. 37.
} 
51. Luego, el caso Velásquez Rodríguez permitió a la Corte IDH sentar firmes bases del Estado de Derecho interamericano, afirmando que "no cabe admitir que el poder pueda ejercerse sin límite alguno o que el Estado pueda valerse de cualquier procedimiento para alcanzar sus objetivos, sin sujeción al derecho o a la moral. Ninguna actividad del Estado puede fundarse sobre el desprecio a la dignidad humana”, ${ }^{69}$

\section{ReFLeXIONES FINALES}

1. La sentencia de la Corte Suprema, en el caso sobre el secuestro calificado de Rudy Cárcamo Ruiz, de mayo de 2012, constituye una manifestación más de que la comunidad estatal se encuentra en los albores de un nuevo paradigma.

2. Este fallo nos pone de frente ante el nuevo Derecho, integrado y global, con nuevas fuentes que el juez local debe tomar en consideración, enfatizando el aspecto material del Derecho. El control de convencionalidad es únicamente una pequeña expresión de este nuevo paradigma, que se viene advirtiendo ya desde hace algún tiempo. Dentro de este control de convencionalidad, la Corte Suprema realiza afirmaciones que están en la línea de los avances del derecho comparado y que confirman la tendencia creciente hacia la humanización de todo el Derecho. Con todo, es necesario advertir que los jueces no utilizan ni recurren al concepto de control de convencionalidad. Algunos de los rasgos característicos de este paradigma son:

A. El derecho humanitario y el derecho internacional de los derechos humanos contienen normas mínimas que los pueblos civilizados consideran como válidas en todas partes y circunstancias. Es imposible no observar aquí la dimensión constitucional de la dignidad humana.

B. El derecho humanitario y el derecho internacional de los derechos humanos contienen normas que consagran un trato humano debido a todos los seres humanos y "ni siquiera la guerra puede privarlos del mínimo que el respeto por el individuo exige". ${ }^{70}$

C. Algunas de las normas del derecho internacional de los derechos humanos son "válidas en todas partes y circunstancias, por estar por encima $[\ldots]$ y

${ }^{69}$ Corte IDH: Caso Velásquez Rodríguez vs. Honduras. Fondo. Sentencia de 29 de julio de 1988. Serie C No 4, para. 154.

${ }^{70}$ Corte Suprema: Secuestro calificado de Rudy Cárcamo Ruiz. Recurso de Casación. Rol No 288-12. Sentencia de fecha 24 de mayo de 2012. Sentencia de Reemplazo. Considerando $11^{\circ}$. 
cuya observancia no está subordinada a deliberaciones preliminares [...]". Otro aspecto de la dimensión constitucional multinivel y del Estado de Derecho, tanto interno como internacional, es el reconocimiento de una serie de normas mínimas, fundamentales, asentadas en valores compartidos universalmente, respecto de las cuales ni las fronteras del Estado, ni la soberanía estatal pueden convertirse en obstáculo o barrera para su real vigencia.

3. El nuevo paradigma requeriría abandonar la visión del derecho nacional como un régimen absoluto, completo y autosuficiente. El nuevo Derecho impone abandonar la práctica del "derecho isla", e incorporar el ordenamiento jurídico estatal de lleno en la era del Derecho global.

4. Esta línea de acción exigiría -como ya se ha dicho- una serie de modificaciones en la forma clásica de entender el Derecho, pero, además, y fundamentalmente, un nuevo enfoque interpretativo y, sobre todo, en el razonamiento jurídico, que exceda el mero horizonte nacional. En este sentido, las herramientas y los instrumentos del derecho comparado serán vitales utensilios para alcanzar un enfoque integrado del Derecho. Por supuesto, la perspectiva incardinada y articulada del derecho internacional, con el derecho nacional, federal y/o local es la tónica que se ha impuesto, ya desde hace algún tiempo, en la época del Derecho global.

5. El ámbito de los derechos humanos es quizás la esfera material donde mayormente se puede observar la presencia de un Derecho global y es quizás la manifestación más cercana a un moderno ius commune. En este contexto, el control de convencionalidad propugnado por la Corte IDH no es sino una técnica de aseguramiento de que al final termine imponiéndose el estándar más alto de protección de los derechos humanos, que no es sino uno de los objetivos fundamentales de un Estado democrático y de Derecho. Esta técnica de aseguramiento está primeramente a cargo -y no podría ser de otro mododel órgano más inmediato encargado de hacer justicia al individuo o grupo, y sólo en defecto de esta realización de la justicia a nivel local, federal o nacional, entra a operar el órgano jurisdiccional internacional. Como se puede observar, aquí aparece resaltada una característica adicional del Derecho global del siglo XXI, esto es, la protección en diferentes niveles -y nunca más, monopólico del poder centralizado del Estado- de los derechos del individuo.

6. Esta exigencia derivada del nuevo paradigma, requiere jueces advertidos y preparados, permanentemente vigilantes frente al derecho internacional y comparado. Se requeriría que los jueces sean versátiles y versados, flexibles y capaces de una gran dosis de desdoblamiento normativo, incorporando el co- 
nocimiento jurídico global; insertos en el mundo; capaces de razonar conforme a los exigentes parámetros y patrones fijados por el Derecho global. Este es un verdadero cambio de paradigma, que requiere un despliegue formal y material, y una apertura hacia los intercambios jurídicos, hacia las interacciones jurídicas, en un mundo en permanente cambio, en permanente evolución, en permanente interacción. En definitiva, se requeriría un juez primeramente dispuesto a asumir este verdadero diálogo, a experimentar todos estos intercambios, y a ser el vector que vehicule todos estos agentes de cambio, de influencias recíprocas, de enriquecimientos mutuos, en definitiva, de fertilizaciones cruzadas.

7. Resta por ver cuál será la actitud y la reacción de los jueces y juristas frente a estos nuevos desafíos que nos depara los albores del siglo XXI, y qué nuevas técnicas se irán desarrollando para hacer frente a la realidad y a todos los efectos e interacciones multidimensionales del Derecho global.

8. Asimismo, resta por ver si el Tribunal Constitucional seguirá la senda del nuevo Derecho que sabiamente ha emprendido, desde hace algún tiempo ya, la Corte Suprema. ${ }^{71}$

\footnotetext{
${ }^{71}$ Antes de finalizar la confección del presente comentario la Corte Suprema de Chile pronunció un fallo de similares características a aquel que aquí se comenta. Vid. Corte Suprema: Secuestro calificado de Héctor Vergara Doxrud. Recurso de Casación. Rol No 12.566-11. Sentencia de fecha 18 de junio de 2012.
} 
